\title{
FATTY ACID COMPOSITION OF RHODOCOCCUS AETHERIVORANS CELLS DURING PHENOL ASSIMILATION
}

\author{
T.M. Nogina, L.A. Khomenko, V.S. Pidgorskyi, M.A. Kharkhota \\ Zabolotny Institute of Microbiology and Virology, NAS of Ukraine, \\ 154 Acad. Zabolotny Str., Kyiv, 03143, Ukraine \\ e-mail:tnogina@ukr.net
}

\begin{abstract}
The ability of microorganisms to survive in unfavorable conditions and maintain their biodegradation activity is mainly associated with changes in the composition of their cellular lipids. One of the factors of negative impact on cells can be their interaction with petroleum hydrocarbons, especially monoaromatic compounds, which are toxic to microorganisms even in small amounts. Aim. To research the changes in the cell fatty acids composition of Rhodococcus aetherivorans UCM Ac-602 strain during phenol degradation. Methods. The cultivation of the strain was carried out in a liquid mineral medium with initial phenol concentration $0.75,1.0$ and $1.5 \mathrm{~g} / \mathrm{L}$ as a sole carbon and energy source. Cells grown in medium with $n$-hexadecane $(7.5 \mathrm{~g} / \mathrm{L})$ and glucose $(5.0 \mathrm{~g} / \mathrm{L})$ were used as controls. Fatty acid methyl esters were obtained by hydrolysis of cells in a $5 \%$ solution of acetyl chloride in methanol, followed by extraction with a mixture of ether-hexane. Identification of methyl esters was performed using a gas chromatography-mass spectrometry system Agilent 6800N/5973 inert (Agilent Technologies, US). The fatty acid content was determined using AgilentChemStation software. Results. Among the cellular fatty acids of $R$. aetherivorans $U C M$ Ac-602 the straight-chain saturated hexadecanoic $\left(C_{16: 0}\right)$, unsaturated hexadecenoic $\left(C_{16: 1}\right.$ cis-9) and octadecenoic $\left(C_{18: 1}\right.$ cis-9) acids as well as branched 10-methyl octadecanoic (tuberculostearic) (10-Me- $\mathrm{C}_{18: 0}$ ) acid were dominated during growth on phenol and glucose. While in $n$-hexadecane grown cells main components of fatty acids pool were saturated tetradecanoic $\left(C_{14: 0}\right)$ and hexadecanoic $\left(C_{16: 0}\right)$ and unsaturated hexadecenoic $\left(C_{16: 1}\right.$ cis-9) acids. The quantitative ratio of individual fatty acids of $R$. aetherivorans UCM Ac-602 cells differed depending on the substrate and incubation time. Under the influence of high phenol concentrations $(1.5 \mathrm{~g} / \mathrm{L})$ there was a threefold increase in the ratio of straight-chain saturated to unsaturated fatty acids in comparison to cells grown on glucose and double increase compared to those grown on n-hexadecane. The amounts of 10-Me- $C_{18: 0}$ fatty acid in cells grown on phenol were 1.8-3.2-fold higher in comparison to cells grown on glucose and 38.3-60.3-fold higher compared to those grown on n-hexadecane. In addition, the content of this acid in cells increased with increasing the time of incubation on phenol. Conclusions. A significant increase in the ratio of straightchain saturated to unsaturated fatty acids in the cells of R. aetherivorans UCM Ac-602 strain during growth on phenol and n-hexadecane in comparison to cells grown on glucose, as well as significant increase of methyl-branched $\left(10-M e-C_{18: 0}\right)$ acid amount in phenol grown cells indicates the possible involvement of these fatty acids in the adaptation of the strain to the assimilation of toxic substances.
\end{abstract}

Keywords: Rhodococcus aetherivorans, fatty acids, phenol, n-hexadecane, glucose.

Microorganisms have evolved to develop many different adaptive mechanisms in response to environmental conditions changing. It is mainly accomplished through changes produced in the lipid composition of their cellular membranes $[1,2]$. Fatty acids of bacteria are the constituent components of cell membranes lipids, which primarily contact and respond to all changes in the environment, supporting the relationship between the structure and function of the membrane. As a rule, all the adaptive mechanisms that the cell induces or activates when exposed to unfavourable growth conditions try to maintain the membrane fluidity at a constant level. This may be achieved by de novo synthesis of membrane lipids or acyl chain remodelling of the fatty acids of existing cellular membrane phospholipids, in particular, by changing the saturation and average chain length of fatty acids $[3,4]$.

Each bacterial strain possesses a unique fatty acid profile, when grown on a specific nutrient medium at a certain temperature, allowing 
their identification. However, when the growth conditions change, prokaryotic cells can alter their fatty acids composition [4]. According to literature data, actinobacteria of the genus Rhodococcus had a cellular fatty acid profile containing straight-chain saturated, unsaturated and 10-methyl-branched fatty acids, and had hexadecanoic $\left(\mathrm{C}_{16: 0}\right)$ as the major fatty acid and relatively high proportions of hexadecenoic $\left(\mathrm{C}_{16: 1}\right)$ and octadecenoic $\left(\mathrm{C}_{18: 1}\right)$ and often 10-methyloctadecanoic (tuberculostearic) $\left(10-\mathrm{Me}-\mathrm{C}_{18: 0}\right)$ acids $[5,6]$. The qualitative composition of fatty acids of rhodococci belonging to different species is almost identical, and differences can be detected, first of all, in the quantitative ratio of individual acids.

In our earlier studies, we established the ability of Rhodococcus aetherivorans UCM Ac-602 strain to completely degrade a high concentration of phenol (up to $2000 \mathrm{mg} / \mathrm{L}$ ) as the only source of carbon and energy, as well as its ability to actively assimilate oil hydrocarbons, in particular, n-hexadecane [7]. It is well known that phenol is a major pollutant of the environment and it is toxic for bacterial cells even at low concentrations. For phenol and phenolic compounds, damage of membrane functions has been proposed as a mechanism of action on microbial cells $[3,8$, 9]. These compounds increasing fluidity of cell membranes disrupting the phospholipid bilayer and interfering with membrane-bound proteins and ultimately causing cell death [2]. One major adaptive mechanism of bacterial cells to the presence of phenols is to increase the degree of saturation of fatty acids in their membrane $[10,11]$. The saturated-unsaturated fatty acid ratios (degree of saturation) are used to assess the bacterial cells adaptation to the effect of toxic substances and changes in environmental conditions [2, 11, 12]. It should be noted that the changes in the fatty acid composition of actinobacterial cells during the assimilation of high concentrations of monoaromatic compounds have not been sufficiently studied, and strains of $R$. aetherivorans in this regard have not been studied.

The aim of this study was to research the changes in the cell fatty acids composition of $R$. aetherivorans UCM Ac-602 strain during phenol degradation.

Materials and methods. The object of the study was $R$. aetherivorans UCM Ac-602 strain which is maintained in the Ukrainian Collection of Microorganisms (UCM) of Danylo Zabolotny Institute of Microbiology and Virology of the
NAS of Ukraine. The strain was isolated in our previous studies from lubricant contaminated soil at the locomotive depot of Odessa railway station as an active destructor of phenol and hydrocarbons $[7,14]$.

Media and culture conditions. Strain R. aetherivorans UCM Ac-602 was grown in the liquid mineral medium ( $\mathrm{g} / \mathrm{L}$ of distilled water): $\mathrm{NH}_{4} \mathrm{NO}_{3}-$ $0.75, \mathrm{Na}_{2} \mathrm{HPO}_{4}-0.73, \mathrm{KH}_{2} \mathrm{PO}_{4}-0.35, \mathrm{NaHCO}_{3}-$ $0.25, \mathrm{MgSO}_{4} \times 7 \mathrm{H}_{2} \mathrm{O}-0.1, \mathrm{MnSO}_{4}-0.002$, $\mathrm{FeSO}_{4} \times 7 \mathrm{H}_{2} \mathrm{O}-0.02$, pH 7.0-7.2 [15]. Phenol was added into the medium as a $5 \%$ water solution to a concentration of $0.75,1.0$ and $1.5 \mathrm{~g} / \mathrm{L}$ as a sole carbon and energy source. Cells grown in medium with n-hexadecane $(7.5 \mathrm{~g} / \mathrm{L})$ and glucose $(5.0 \mathrm{~g} / \mathrm{L})$ were used as controls. The cultivation on each substrate was carried out in $750 \mathrm{~mL}$ Erlenmeyer flasks with $100 \mathrm{~mL}$ of medium at $28{ }^{\circ} \mathrm{C}$ on the shaker (220 rpm). Samples were taken after 24, 48 and $72 \mathrm{~h}$ growth on phenol, after $72 \mathrm{~h}$ growth on $\mathrm{n}$-hexadecane and after $24 \mathrm{~h}$ growth on glucose. The cell pellet was separated by centrifugation (5000 rpm, $15 \mathrm{~min}, 4{ }^{\circ} \mathrm{C}$ ) and washed twice with distilled water.

Fatty acid determination. The fatty acid composition of cellular lipids was studied by gas chromatography-mass spectrometry on an Agilent 6890N/5973 inert instrument (Agilent Technologies, USA) using an HP-5MS capillary column $(30 \mathrm{~m} \times 0.25 \mathrm{~mm} \times 0.25 \mu \mathrm{m})(\mathrm{J} \& \mathrm{~W}$ Scientific, USA). To obtain methyl esters of fatty acids, a $2 \%$ solution of acetyl chloride in methanol was added to the biomass of the studied strains and kept at $80^{\circ} \mathrm{C}$ for $2 \mathrm{~h}$. The methyl esters were extracted three times with heptane and evaporated to $200 \mu \mathrm{L}$. The separation was carried out in a gradient mode from 150 to $250{ }^{\circ} \mathrm{C}$, the rate of temperature increase was $4{ }^{\circ} \mathrm{C} / \mathrm{min}$, the carrier gas was helium, and the flow rate through the column was $1 \mathrm{~mL} / \mathrm{min}$. Identification of methyl esters was performed using the NIST02 mass spectra libraries and a standard mixture of bacterial fatty acid methyl esters (4708-U Supelco, USA). Fatty acid content was expressed as a percentage (\%) of total peak area.

Statistics. All experiments were performed in triplicate. The obtained data were analyzed with Microsoft Office Excel 2010 software standard package.

Results. In this paper the effect of different phenol concentration and cultivation time on the fatty acid composition of $R$. aetherivorans UCM Ac-602 at phenol degradation were investigated. 
The obtained results are presented in Table 1.

Effects of phenol on fatty acid composition of R. aetherivorans UCM Ac-602 in comparison to glucose or n-hexadecane

To assess the effect of phenol on fatty acid composition of $R$. aetherivorans UCM Ac-602 compared to that on n-hexadecane or glucose, the fatty acid profiles of cells were compared in cultures reaching the stationary growth phase at cultivation on these substrates. In previous studies, we have shown that $R$. aetherivorans UCM Ac602 cells grown at a phenol concentration of $0.75,1.0$ and $1.5 \mathrm{~g} / \mathrm{L}$ as a sole carbon and energy source reached the stationary growth phase and completely degraded phenol after 24, 48 and $72 \mathrm{~h}$ respectively [7]. Samples of control cells grown on the same medium with n-hexadecane and glucose were taken after 72 and 24 hours, respectively, until the cultures reached the stationary growth phase.

For the interpretation of the obtained results, all identified fatty acids were divided into three groups: straight-chain saturated, straightchain unsaturated and methyl-branched fatty acids. The results showed that straight-chain saturated acids predominated in the cells during each growth substrate assimilation (Table 1). The amount of these acids ranged from 37.7 to $63.5 \%$ of the total fatty acids, whereas the content of monounsaturated acids was $14.2-43.0 \%$. In the fatty acid pool of this strain among straight-chain saturated and unsaturated fatty acids predominated hexadecanoic $\left(\mathrm{C}_{16: 0}\right)$, hexadecene $\left(\mathrm{C}_{16: 1}\right.$ cis-9) and octadecene $\left(\mathrm{C}_{18: 1}\right.$ cis-9) acids. The significant amount (excluding growth on $n$-hexadecane) of branched 10-methyl octadecanoic $\left(10-\mathrm{Me}_{18: 0}\right)$ acid also was found.

\section{Table 1}

\section{Percentage of total fatty acids from $R$. aetherivorans UCM Ac-602 grown in the presence of phenol, glucose $(5.0 \mathrm{~g} / \mathrm{L})$ or $n$-hexadecane $(7.5 \mathrm{~g} / \mathrm{L})$}

\begin{tabular}{|c|c|c|c|c|c|c|c|c|c|c|}
\hline \multirow{4}{*}{ Fatty acids } & \multicolumn{10}{|c|}{ Percentage of total fatty acids } \\
\hline & \multicolumn{8}{|c|}{ Phenol } & \multirow{3}{*}{ Glucose } & \multirow{3}{*}{ n-Hexadecane } \\
\hline & \multicolumn{3}{|c|}{$0.75 \mathrm{~g} / \mathrm{L}$} & \multicolumn{3}{|c|}{$1.0 \mathrm{~g} / \mathrm{L}$} & \multicolumn{2}{|c|}{$1.5 \mathrm{~g} / \mathrm{L}$} & & \\
\hline & $24 \mathrm{~h}$ & $48 \mathrm{~h}$ & $72 \mathrm{~h}$ & $24 \mathrm{~h}$ & $48 \mathrm{~h}$ & $72 \mathrm{~h}$ & $48 \mathrm{~h}$ & $72 \mathrm{~h}$ & & \\
\hline $\mathrm{C}_{10: 0}$ & - & - & - & - & - & - & - & - & - & 0.6 \\
\hline $\mathrm{C}_{12: 0}$ & - & - & - & - & - & - & - & - & - & 3.6 \\
\hline $\mathrm{C}_{13: 0}$ & - & - & - & - & - & - & - & - & - & 0.6 \\
\hline $\mathrm{C}_{14: 0}$ & 0.6 & 0.6 & 0.6 & 1.0 & 0.9 & 0.9 & 1.2 & 1.1 & 1.3 & 11.8 \\
\hline $\mathrm{C}_{15: 0}$ & 0.6 & 1.0 & 1.0 & 0.8 & 0.9 & 1.0 & 1.0 & 0.9 & 1.6 & 1.6 \\
\hline $\mathrm{C}_{16: 1}$ cis-9 & 13.9 & 13.9 & 13.3 & 14.8 & 13.6 & 13.4 & 10.0 & 8.0 & 14.5 & 25.4 \\
\hline $\mathrm{C}_{16: 0}$ & 33.8 & 35.8 & 36.0 & 34.2 & 31.6 & 36.1 & 39.4 & 38.3 & 31.2 & 43.1 \\
\hline $\begin{array}{l}\text { 14-Me- } \mathrm{C}_{16: 0} \\
\text { (14-methyl hexadecanoic) }\end{array}$ & - & - & - & - & - & - & - & - & - & 1.5 \\
\hline $\mathrm{C}_{17: 0}$ & 1.6 & 2.0 & 2.0 & 0.9 & 2.5 & 2.5 & 1.7 & 1.6 & 4.4 & - \\
\hline $\mathrm{C}_{18: 1}$ & 26.4 & 6.8 & 5.3 & 28.4 & 24.2 & 20.4 & 15.2 & 6.2 & 28.5 & 3.1 \\
\hline $\mathrm{C}_{18: 0}$ & 1.1 & 1.2 & 1.0 & 1.0 & 4.1 & 3.3 & 1.3 & 2.7 & 4.4 & 2.2 \\
\hline $\begin{array}{l}\text { 10-Me- } \mathrm{C}_{18: 0} \\
\text { (10-methyl-octadecanoic) }\end{array}$ & 20.0 & 36.9 & 39.1 & 16.0 & 19.4 & 22.9 & 25.2 & 35.0 & 10.8 & 0.6 \\
\hline Sum of straight saturated & 37.7 & 40.6 & 40.6 & 37.9 & 40.0 & 43.6 & 44.6 & 44.6 & 42.9 & 63.5 \\
\hline Sum of straight unsaturated & 40.3 & 20.8 & 18.6 & 43.2 & 37.8 & 33.7 & 25.2 & 14.2 & 43.0 & 25.8 \\
\hline
\end{tabular}

Legend: The amount of acids is presented as a percentage of the average of 3 measurements; "_" acid is not detected, or its amount is less than $0.3 \%$. Standard deviation did not exceed $7 \%$ of a particular value.

The analysis of fatty acids extracted from control cells grown on $n$-hexadecane showed that $R$. aetherivorans UCM Ac-602 on this substrate differed in fatty acid profile compared to phenol and glucose. The most remarkable differences consisted in a low content of octadecene $\mathrm{C}_{18: 1}$ cis-9 and 10-methyl octadecanoic (10-Me- $\left.\mathrm{C}_{18: 0}\right)$ acids and a higher amount of tetradecanoic $\mathrm{C}_{14: 0}$ $(11.8 \%)$, as well as hexadecanoic $\mathrm{C}_{16.0}(43.1 \%)$ and hexadecenoic $\mathrm{C}_{16: 1}$ cis-9 (25.4\%) acids. Only in $n$-hexadecane grown cells of this strain decanoic $\left(\mathrm{C}_{\text {10:0 }}\right)$, dodecanoic $\left(\mathrm{C}_{12: 0}\right)$, tridecanoic $\left(\mathrm{C}_{13: 0}\right)$ and 
14-methyl-hexadecanoic (14-Me-C $\mathrm{C}_{16: 0}$ ) fatty acids were detected (Table 1).

Changes in the content of straight-chain saturated and unsaturated fatty acids mainly affected the saturated/unsaturated ratio (the degree of saturation of fatty acids). In this strain it showed tendency to increase with increasing phenol concentration (Fig.1). Degree of saturation of fatty acids (0.9-1.1) at lower phenol concentrations $(0.75$ and $1.0 \mathrm{~g} / \mathrm{L})$ is close to that during growth on glucose. However, with increasing of phenol concentration to $1.5 \mathrm{~g} / \mathrm{L}$ the amount of straightchain cis-unsaturated fatty acids decreased significantly and saturated/unsaturated ratio of fatty acids increased to 3.1 which is 1.2 -fold higher than on hexadecane.

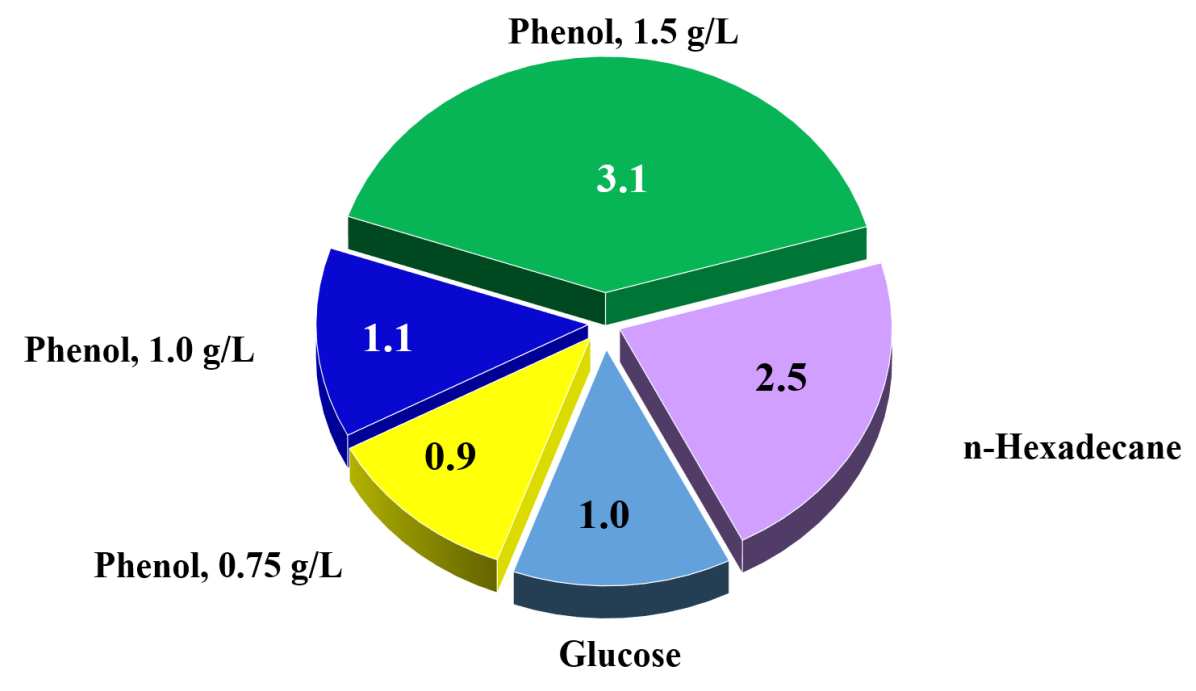

\section{F i g. 1. Degree of saturation (saturated/unsaturated ratio) of fatty acids in $R$. aetherivorans UCM Ac-602 cells grown on phenol compared to glucose and n-hexadecane}

Under the influence of phenol, the abundance of methyl-branched fatty acids in tested strain also changed. Thus, the content of branched 10-methyl octadecanoic (10-Me- $\left.\mathrm{C}_{18: 0}\right)$ acid increased 1.8-3.2fold in comparison to glucose and 38.3-60.3-fold compared to hexadecane. With an increase of phenol concentration to $1.5 \mathrm{~g} / \mathrm{L}$, the amount of 10 Me- $\mathrm{C}_{18: 0}$ acid in the cells of this strain increased from $19.4-20.0 \%$ to $35 \%$, while the content of unsaturated hexadecenoic $\mathrm{C}_{16: 1}$ cis-9 acid decreased from $13.6-13.9 \%$ to $8.0 \%$ and octadecenoic $\mathrm{C}_{18: 1}$ cis-9 acid decreased from $24.2-26.4 \%$ to $6.2 \%$. The spectrum of fatty acids detected in cells grown at phenol $(1.5 \mathrm{~g} / \mathrm{L})$ compared to those on glucose are shown in Fig. 2.

Effects of cultivation time on fatty acid composition of R. aetherivorans UCM Ac-602 at phenol degradation

To assess the effect of cultivation time on the cells fatty acid composition, it was compared in cultures grown for 24,48 and $72 \mathrm{~h}$ at a phenol concentration of 0.75 and $1.0 \mathrm{~g} / \mathrm{L}$ and 48 and 72 $\mathrm{h}$ at a concentration of $1.5 \mathrm{~g} / \mathrm{L}$ (Table 1 ). It was found that there was a little change in the amount of most fatty acids, with the exception of unsaturated $\mathrm{C}_{18: 1}$ cis-9 and methyl-branched $10-\mathrm{Me}-\mathrm{C}_{18: 0}$ fatty acids, with an increase of the incubation time at the same phenol concentration. At the initial phenol concentration of $0.75,1.0$ and $1.5 \mathrm{~g} / \mathrm{L}$, after $72 \mathrm{~h}$ of growth, a decrease of the amount of unsaturated $\mathrm{C}_{18: 1}$ cis-9 fatty acid was 5.0, 1.4 and 2.4-fold, respectively. The content of methyl-branched 10Me- $\mathrm{C}_{18: 0}$ fatty acid for this time was 1.9, 1.4 and 1.4-fold higher, respectively. Thus, with an increase in the incubation time of the strain, there was a decrease in the amount of straight-chain unsaturated acids and an increase in the amount of methylbranched fatty acids. The calculated on the basis of the data presented in Table 1 ratio of straightchain saturated to unsaturated acids at each phenol concentration increased with an increase of the incubation time: at an initial phenol concentration of $0.75 \mathrm{~g} / \mathrm{L}$, this parameter increased 2.4-fold after $72 \mathrm{~h}$ of growth, at a phenol concentration of $1.0 \mathrm{~g} / \mathrm{L}$, it increased 1.3-fold, and at a concentration of $1.5 \mathrm{~g} / \mathrm{L}-1.7$-fold.

Discussion. Actinobacteria of the genus Rhodococcus possess the versatile ability to catabolize a variety of xenobiotic organic pollutants and are useful for the bioremediation of polluted environments $[16,17]$. Among the members of 
$\mathbf{A}$

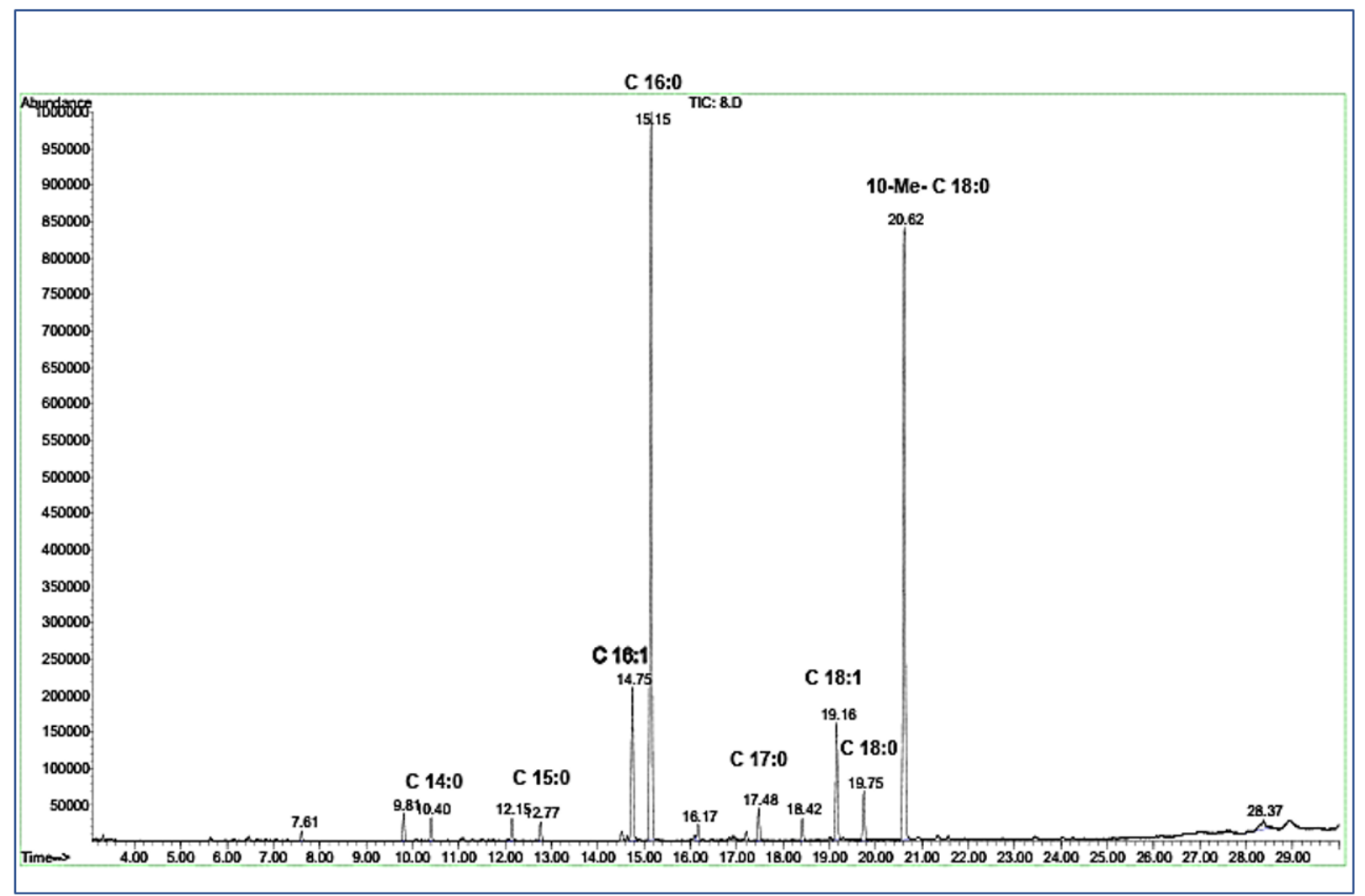

B

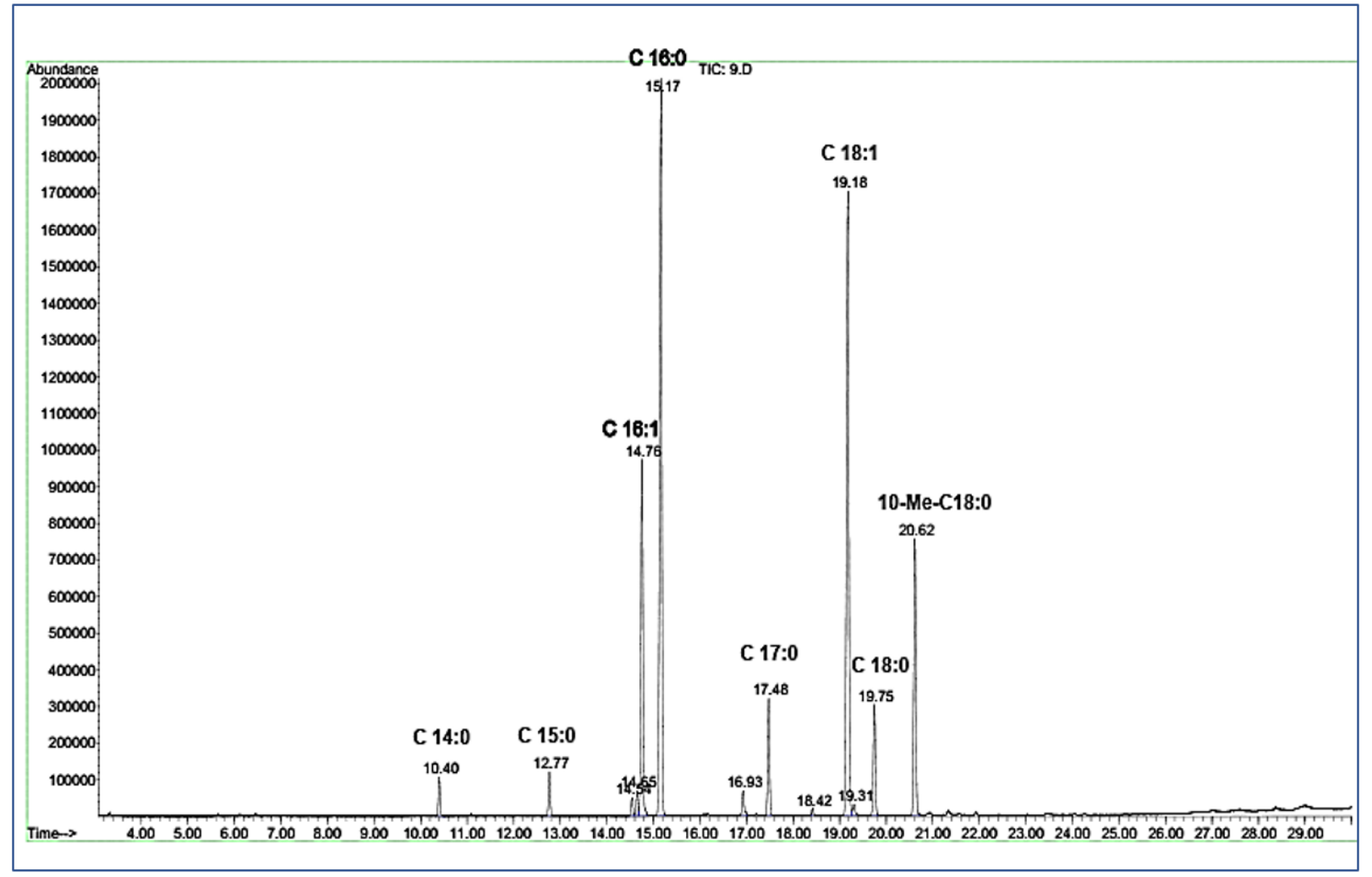

F i g. 2. Gas chromatography-mass spectrometry analysis on HP-5MS capillary column of fatty acid methyl esters from $R$. aetherivorans UCM Ac-602 strain grown with (a) phenol (1.5 g/L) and (b) glucose 
this genus, $R$. aetherivorans is a species of special interest in the biodegradation of various resistant to degradation pollutants, such as noncyclic and cyclic ethers [18-20], aliphatic and aromatic hydrocarbons [21] and chlorinated organic compounds [22]. Our previous studies have shown that $R$. aetherivorans UCM Ac-602 strain efficiently degraded phenol as well as n-hexadecane, kerosene, diesel fuel and transformer oil [7]. It is known that changes in the lipid composition of cells, primarily fatty acids, are of great importance in the adaptation of microorganisms to the assimilation of membraneactive compounds, in particular phenol and its derivatives $[3,8,9,11]$. In this paper, we found that the amount of straight-chain saturated and unsaturated fatty acids in $R$. aetherivorans UCM Ac-602 at the assimilation of phenol, glucose and n-hexadecane as the sole of carbon and energy source ranged from 58.8 to $92.0 \%$ of the total fatty acid content of cells. Among them the amount of fatty acids with an even number of a carbon was equal to $56.3-86.2 \%$. Regardless of the growth substrate, in the cellular fatty acid composition, as in other species of the genus Rhodococcus, predominated straight-chain saturated and unsaturated fatty acids and constantly presents branched 10-methyl octadecanoic (tuberculostearic) (10-Me- $\left.\mathrm{C}_{18: 0}\right)$ acid, which is typical cellular fatty acid of Rhodococcus species $[5,6]$. The predominated fatty acids in cells grown on phenol and glucose were hexadecanoic $\left(\mathrm{C}_{16: 0}\right)$, hexadecenoic $\left(\mathrm{C}_{16: 1}\right.$ cis-9), octadecenoic $\left(\mathrm{C}_{18: 1}\right.$ cis9) and 10-methyl-octadecanoic (tuberculostearic) $\left(10-\mathrm{Me}-\mathrm{C}_{18: 0}\right)$ acids at the beginning of the stationary growth phase. Among the fatty acids of cells grown on $n$-hexadecane the highest amount of hexadecanoic $\left(\mathrm{C}_{16: 0}\right)$, tetradecanoic $\left(\mathrm{C}_{14: 0}\right)$ and hexadecenoic $\left(\mathrm{C}_{16: 1}\right.$ cis-9) acids were detected.

According to literature data, during growth on toxic substrate bacteria are able to change the fluidity of their membrane by synthesis of membrane lipids with different ratios of saturated to unsaturated fatty acids [11]. In Escherichia coli, membrane modification was found to correlate with increased cell resistance to toxic compounds. The addition of saturated fatty acids to the culture medium of $E$. coli led to an increase in phenol resistance, while the addition of cis-unsaturated fatty acids did not affect the degree of saturation of membrane lipids or the toxicity of compounds for cells [10]. In the cells of the phenol-degrading Pseudomonas putida P8 strain a correlation was also observed between an increase in the degree of saturation of membrane fatty acids and an increased tolerance to the toxic compound [11].

In our study it was found that at lower phenol concentrations $(0.75-1.0 \mathrm{~g} / \mathrm{L})$, which according to our earlier data [7] insignificantly affect the viability and growth rate of the strain, the quantitative content of fatty acids and the ratio of saturated to unsaturated acids were close to those identified on glucose. The main difference was associated with the fact that the phenol grown cells contained a significantly higher amount of branched 10-methyloctadecanoic (tuberculostearic) $10-\mathrm{Me}-\mathrm{C}_{18 \cdot 0}$ fatty acid. At these phenol concentrations, the amount of 10-Me- $\mathrm{C}_{18: 0}$ fatty acid was 1.8-fold higher than that on glucose. At a phenol concentration of $1.5 \mathrm{~g} / \mathrm{L}$, which as we established earlier [7], inhibits the growth and development of the strain, the more significant changes were revealed: the ratio of straight-chain saturated to unsaturated acids 3.1fold exceeded those on glucose, the content of branched 10-Me- $\mathrm{C}_{18: 0}$ fatty acid was 3.2-fold higher while an amount of unsaturated $\mathrm{C}_{16: 1}$ cis-9 and $\mathrm{C}_{18: 1}$ cis-9 fatty acids decreased 1.8-fold and 4.6-fold respectively. The increase of the cultivation time of $R$. aetherivorans UCM Ac-602 strain at different initial phenol concentrations were accompanied by a significant decrease (1.4-2.2-fold) in the amount of unsaturated $\left(\mathrm{C}_{18: 1}\right.$ cis-9) fatty acid in the cells and an increase of the amount (1,4-1.9-fold) of methylbranched acids (10-Me- $\left.\mathrm{C}_{18: 0}\right)$.

It is known that unsaturated fatty acids play a key role in membrane fluidity maintaining. This is due particularly to the fact that, unlike saturated acyl chains, which are assembled tightly in membrane lipids, unsaturated fatty acids provide stearic hindrances due to rigid kink of the cis-double bonds that leads to a much poorer packing of unsaturated acids chain [23]. It is also found that 10-methyl octadecanoic $\left(10-\mathrm{Me}-\mathrm{C}_{18: 0}\right)$ fatty acid are located in cell envelope lipids, mainly lipoarabinomannan, which is one of the major components of the cell envelope of actinobacteria [24]. According to the literature membrane incorporation of branchedchain fatty acids in particular $10-\mathrm{Me}_{\mathrm{C}} \mathrm{C}_{18: 0}$ acid may stabilize the gel phase of the membrane bilayers, an effect which can be explained by a more effective packing of the lipids which causes reduced diffusion across membranes [25]. Thus, our data on a significant decrease in the amount of unsaturated $\mathrm{C}_{16: 1}$ cis-9 and $\mathrm{C}_{18: 1}$ cis-9 fatty acids and increase of methyl-branched-chain fatty acids content in phenol grown $R$. aetherivorans UCM Ac-602 cells in comparison to glucose grown cells may indicate on participation of these acids in the protection of the cells of this strain from disruption 
of membrane-bound structural components of the cell wall caused by this toxicant. Similar results have been obtained by other authors studying the fatty acid composition of cells of Rhodococcus opacus GM-14, GM-29 and 1CP strains growing on toxic aromatic compounds [24]. For example, in these on phenol grown strains the cellular contents of unsaturated cis- $\mathrm{C}_{16: 1}$ and cis- $\mathrm{C}_{18: 1}$ fatty acids decreased 3.4-6.7-fold and 2.7-5.1fold respectively while the content of 10-methyl branched (10-Me-C $\mathrm{C}_{18: 0}$ ) fatty acid was 4,8-9,2-fold higher than those grown in mineral medium with fructose. Moreover, in the strains of $R$. opacus, an increase of the amount of cellular 10-methyl branched fatty acids was observed with an increase of phenol concentration in the medium.

The fatty acid composition of $R$. aetherivorans UCM Ac-602 cells growing on n-hexadecane significantly differed from that found on phenol and glucose. The predominant fatty acids in n-hexadecane grown cells were $\mathrm{C}_{16: 0}(43.1 \%)$, $\mathrm{C}_{16: 1}(25.4 \%)$ and $\mathrm{C}_{14: 0}(11.8 \%)$ obtained directly from the carbon skeleton of n-hexadecane. The obtained data correlate with the results of studying the cellular fatty acid composition of other representatives of hydrocarbon-oxidizing strains of actinobacteria, in particular Mycobacterium convolutum R22 [26] and Mycobacterium vaccae JOB5 [27], for which it has been demonstrated that the n-alkane substrate was incorporated into the cellular lipids after monoterminal oxidation. The presence in $R$. aetherivorans UCM Ac-602 cells a small amount of straight-chain unsaturated octadecenoic $\mathrm{C}_{18: 1}$ cis-9 fatty acid and a higher amounts of tetradecanoic $\mathrm{C}_{14: 0}$, hexadecanoic $\mathrm{C}_{16: 0}$ and hexadecenoic $\mathrm{C}_{16: 1}$ cis-9 fatty acids, which were observed in n-hexadecane grown cells in comparison to those grown on glucose similar to the results obtained for the another strains of the genus Rhodococcus - Rhodococcus sp. Q15 [12] and Rhodococcus erythropolis GH [28].

It should be noted that in n-hexadecane grown cells of $R$. aetherivorans UCM Ac-602 the saturated/unsaturated fatty acids ratio (degree of saturation) 2.2-fold exceeded that in glucose grown cells. This may indicate that one of the important mechanisms of this strain adaptation to the assimilation of $n$-hexadecane in comparison with glucose is a significant increase in the amount of saturated fatty acids, which are known [3, 29] increase the rigidity of the cell wall due to the continuous packing of their acyl chains.
Conclusions. An increase in the ratio of straight-chain saturated to unsaturated cellular fatty acids, as well as increasing the amount of methyl-branched (10-Me- $\mathrm{C}_{18: 0}$ ) acid may be one of the major mechanisms for the protection of $R$. aetherivorans UCM Ac-602 cells from phenol substrate toxicity. A feature of the fatty acid composition in n-hexadecane grown cells of the strain is the presence of a significant amount of straight-chain saturated fatty acids synthesized directly from the carbon chain of this hydrocarbon; the main possible mechanism of cell adaptation of R.aetherivorans UCM Ac-602 to the assimilation of n-hexadecane is an increase of the saturated/ unsaturated fatty acids ratio.

Financial support. This work was supported by the National Academy of Sciences of Ukraine, grant No. 0117U004514 "Elucidation of the types of regulation of vital processes of microorganisms under the influence of exogenous factors and their adaptation to environmental conditions using experimental approaches and bioinformative analysis" (within the framework of the target program of scientific research of the Department of Biochemistry, Physiology and Molecular Biology of the NAS of Ukraine "Molecular-genetic and biochemical mechanisms of regulation of cellular and systemic interactions in physiological and pathological conditions").

\section{ЖИРНОКИСЛОТНИЙ СКЛАД КЛITИН RHODOCOCCUS AETHERI- VORANS ПРИ ЗАСВОСННІ ФЕНОЛУ}

\author{
Т.М. Ногіна, Л.А. Хоменко, \\ В.С. Підгорський, М.А. Хархота
}

Інститут мікробіологї̈ $і$ вірусологї̈ ім. Д.К. Заболотного НАН України, вул. Академіка Заболотного, 154, Київ, 03143, Україна

Резюме

Здатність мікроорганізмів виживати в несприятливих умовах і зберігати свою біодеструктивну активність, в основному, пов'язана зі змінами у складі їх клітинних ліпідів. Одним з факторів негативного впливу на клітини може бути їх взаємодія 3 нафтовими вуглеводнями, особливо 3 моноароматичними речовинами, які навіть в невеликих кількостях токсичні для мікроорганізмів. Мета. Дослідити зміни у жирнокислотному складі клітин штаму Rhodococcus aetherivorans UCM Ac-602 
при деградації фенолу. Методи. Культивування штаму проводили в рідкому мінеральному середовищі з фенолом $(0.75,1.0$ та 1.5 г/л) як єдиним джерелом вуглецю та енергії. Клітини, вирощені на середовищі з н-гексадеканом (7.5 г/л) та глюкозою (5.0 г/л), використовували як контролі. Метилові ефіри жирних кислот отримували гідролізом клітин в $5 \%$ розчині ацетилхлориду в метанолі 3 наступною екстракцією сумішшю ефір-гексан. Ідентифікацію метилових ефірів проводили за допомогою хромато-мас-спектрометричної системи Agilent $6800 \mathrm{~N} / 5973$ inert (Agilent Technologies, US). Вміст жирних кислот визначали за допомогою програмного забезпечення AgilentChemStation. Результати. Серед жирних кислот клітин штаму R. aetherivorans UCM Ac-602 при рості на фенолі та глюкозі переважали прямоланцюгові: насичена гексадеканова $\left(\mathrm{C}_{16: 0}\right)$, ненасичені гексадеценова $\left(\mathrm{C}_{16: 1}\right.$ иис-9) і октадеценова $\left(\mathrm{C}_{18: 1}\right.$ иис-9) кислоти, а також розгалужена 10 -метил-октадеканова (туберкулостеаринова) (10-Ме-С 18:0 $)$ кислота. В клітинах, що виросли на н-гексадекані, основними компонентами пулу жирних кислот були насичені тетрадеканова $\left(\mathrm{C}_{14: 0}\right)$ та гексадеканова $\left(\mathrm{C}_{16: 0}\right)$ та ненасичена гексадеценова $\left(\mathrm{C}_{16: 1}\right.$ иис-9) кислоти. Кількісне співвідношення індивідуальних жир-

1. Konings WN, Albers S-V, Koning S, Driessen AJM. The cell membrane plays a crucial role in survival of bacteria and archaea in extreme environments. Antonie Van Leeuwenhoek. 2002; 81:61-72.

2. De Carvalho CCCR. Adaptation of Rhodococcus to Organic Solvents. In: Alvarez HM, editor. Biology of Rhodococcus. Microbiology Monographs. (16) 2nd ed. Springer Nature Switzerland AG; 2019. p.103-135.

3. Heipieper HJ, Weber FJ, Sikkema J, Keweloh H, de Bont JAM. Mechanisms of resistance of whole cells to toxic organic solvents. Trends in Biotechnology. 1994; 12(10):409-415.

4. De Carvalho CCCR, Caramujo MJ. The various roles of fatty acids. Molecules. 2018; 23(10): 2583.

5. Ivshina IB. [Bacteria of the genus Rhodococcus (immunodiagnostics, detection, biodiversity)]. A dissertation in the form of a scientific report for the degree of doctor of biological sciences. Perm; 1997. Russian. них кислот штаму $R$. aetherivorans УКМ Ас-602 змінювалося залежно від субстрату та часу інкубації. Під впливом високих концентрацій фенолу (1.5 г/л) відбувалось збільшення в 3 рази співвідношення нерозгалужених насичених і ненасичених кислот порівняно з клітинами, що виросли на глюкозі, та в 2 рази - порівняно з тими, що виросли на н-гексадекані. Кількість 10-Ме- $\mathrm{C}_{18: 0}$ кислоти в клітинах після росту на фенолі була у 1,8 3,2 рази вищою порівняно 3 клітинами, що виросли на глюкозі, та у 38,3-60,3 рази вищою, ніж у тих, що виросли на н-гексадекані. Крім того, вміст цієї кислоти в клітинах підвищувався і при збільшенні тривалості культивування штаму на фенолі. Висновки. Значне збільшення співвідношення між нерозгалуженими насиченими та ненасиченими жирними кислотами в клітинах штаму R. aetherivorans УКМ Ас-602 при рості на фенолі і н-гексадекані порівняно з клітинами, вирощеними на глюкозі, а також збільшення кількості метилрозгалуженої (10-Ме-С 18:0) $_{\text {) }}$ кислоти в клітинах, що виросли на фенолі, свідчить про можливу участь цих жирних кислот у адаптації штаму до засвоєння токсичних речовин.

Ключові слова: Rhodococcus aetherivorans, жирні кислоти, фенол, н-гексадекан, глюкоза.

6. Yoon JH, Cho YG, Kang SS, Kim SB, Lee ST, Park YH. Rhodococcus koreensis sp. nov., a 2,4-dinitrophenol-degrading bacterium. Int J Syst Evol Microbiol. 2000; 50(3):1193-1201.

7. Nogina T, Fomina M, Dumanskaya T, et al. A new Rhodococcus aetherivorans strain isolated from lubricant-contaminated soil as a prospective phenol-biodegrading agent. Appl Microbiol Biotechnol. 2020; 104:3611-3625.

8. Keweloh H, Weyrauch G, Rehm HJ. Phenolinduced membrane changes in free and immobilized Escherichia coli. Appl Microbiol Biotechnol. 1990; 33:66-71.

9. Heipieper HJ, Keweloh H, Rehm HJ. Influence of phenols on growth and membrane permeability of free and immobilized Escherichia coli. Appl Environ Microbiol. 1991; 57(4):1213-1217.

10. Keweloh H, Diefenbach R, Rehm HJ. Increase of phenol tolerance of Escherichia coli by alterations of the fatty acid composition of the membrane lipids. Arch Microbiol. 1991; 157(1):49-53. 
11. Heipieper HJ, Diefenbach R, Keweloh H. Conversion of cis unsaturated fatty acids to trans, a possible mechanism for the protection of phenol-degrading Pseudomonas putida P8 from substrate toxicity. Appl Environ Microbiol. 1992; 58(6):1847-1852.

12. Whyte LG, Slagman SJ, Pietrantonio F, Bourbonnière L, Koval SF, Lawrence JR, Inniss WE, Greer CW. Physiological adaptations involved in alkane assimilation at low temperatures by Rhodococcus sp. strain Q15. Appl Environ Microbiol. 1999; 65(7):2961-2968.

13. Mrozik A, Łabużek S, Piotrowska-Seget Z. Changes in fatty acid composition in Pseudomonas putida and Pseudomonas stutzeri during naphthalene degradation. Microbiological Research. 2005; 160:149-157.

14. Patent UA №124128 for a utility model. Pidgorsky VS, Nogina TM, Dumanskaya TU, Khomenko LA. [The strain of actinobacteria Rhodococcus aetherivorans is a phenol destructor]. Publ. 03.26.2018 Bull. №6. Ukrainian.

15. Shumkova ES, Solyanikova IP, Plotnikova EG, Golovleva LA. Phenol degradation by Rhodococcus opacus strain 1G. Appl Biochem Microbiol. 2009; 45(1):43-49.

16. Larkin MJ, Kulakov LA, Allen CC. Biodegradation and Rhodococcus: masters of catabolic versatility. Curr Opin Biotechnol. 2005; 16:282290.

17. Martínková L, Uhnáková B, Pátek M, Nesvera J, Kren V. Biodegradation potential of the genus Rhodococcus. Environ Int. 2009; 35(1):162-177.

18. Goodfellow M, Jones AL, Maldonado LA, Salanitro J. Rhodococcus aetherivorans sp. nov., a new species that contains methyl t-butyl etherdegrading actinomycetes. Syst Appl Microbiol. 2004; 27(1):61-65.

19. Tajima T, Hayashida N, Matsumura R, Omura A, Nakashimada Y, Kato J. Isolation and characterization of tetrahydrofuran-degrading Rhodococcus aetherivorans strain M8. Process Biochem. 2012; 47(11):1665-1669.

20. Inoue D, Tsunoda T, Yamamoto N, Ike M, Sei K. 1,4-Dioxane degradation characteristics of Rhodococcus aetherivorans JCM 14343. Biodegradation. 2018; 29(3):301-310.
21. Auffret M, Labbé D, Thouand G, Greer CW, Fayolle-Guichard F. Degradation of a mixture of hydrocarbons, gasoline, and diesel oil additives by Rhodococcus aetherivorans and Rhodococcus wratislaviensis. Appl Environ Microbiol. 2009; 75(24):7774-7782.

22. Frascari D, Pinelli D, Nocentini M, Fedi S, Pii Y, Zannoni D. Chloroform degradation by butane-grown cells of Rhodococcus aetherivorans BCP1. Appl Microbiol Biotechnol. 2006; 73:421-428.

23. Garba L, Ali MSM, Oslan SN, Abd Rahman RNZR. Review on fatty acid desaturases and their roles in temperature acclimatisation. J Appl Sci. 2017; 17(6):282-295.

24. Tsitko IV, Zaitsev GM, Lobanok AG, Salkinoja-Salonen MS. Effect of aromatic compounds on cellular fatty acid composition of Rhodococcus opacus. Appl Environ Microbiol. 1999; 65(2):853-855.

25. Lindström F, Thurnhofer S, Vetter W, Gröbner G. Impact on lipid membrane organization by free branched-chain fatty acids. Phys Chem Chem Phys. 2006; 8:4792-4797.

26. Ascenzi JM, Vestal JR. Regulation of fatty acid biosynthesis by hydrocarbon substrates in $M y$ cobacterium convolutum. J Bacteriol. 1979; 137(1):384-390.

27. King DH, Perry JJ. The origin of fatty acids in the hydrocarbon-utilizing microorganism $M y$ cobacterium vaccae. Can J Microbiol. 1975; 21(1):85-89.

28. Atakishieva YAYU, Ismayilova LM. [Lipogenesis of a hydrocarbon-degrading bacterium Rhodococcus erythropolis GH]. In: Materials of the international scientific-practical conference Biotechnology of microorganisms; 2019 Nov 27-29; Minsk, Belarus. Minsk: Ecoperspectiva, 2019. p. 24-7. Russian.

29. Murínová S, Dercová K. Response mechanisms of bacterial degraders to environmental contaminants on the level of cell walls and cytoplasmic membrane. Int J Microbiol. 2014; 1-16. doi:10.1155/2014/873081.

Received 15.03.2021 